\title{
Pyruvate carboxylase from Corynebacterium glutamicum : characterization, expression and inactivation of the pyc gene
}

\author{
Petra G. Peters-Wendisch, ${ }^{1}+$ Caroline Kreutzer, ${ }^{1}$ Jörn Kalinowski, ${ }^{2}$ \\ Miroslav Pátek, ${ }^{3}$ Hermann Sahm ${ }^{1}$ and Bernhard J. Eikmanns ${ }^{1} \ddagger$
}

1 Institut für Biotechnologie, Forschungszentrum Jülich, D-52425 Jülich, Germany

2 Lehrstuhl für Genetik, Universităt Bielefeld Postfach 100131, D-33501 Bielefeld, Germany

3 Institute of Microbiology, Academy of Sciences of the Czech Republic, Vídenská 1083, CZ-14220 Prague, Czech Republic

\author{
Author for correspondence: Petra G. Peters-Wendisch. Tel: +492461 612544. Fax: +49 2461612710. \\ e-mail : peterswe@nature.berkeley.edu
}

In addition to phosphoenolpyruvate carboxylase (PEPCX), pyruvate carboxylase (PCX) has recently been found as an anaplerotic enzyme in the amino-acidproducing bacterium Corynebacterium glutamicum. Using oligonucleotides designed according to conserved regions of $\mathrm{PCX}$ amino acid sequences from other organisms, a 200 bp fragment central to the C. glutamicum PCx gene (pyc) was amplified from genomic DNA by PCR. This fragment was then used to identify and to subclone the entire $C$. glutamicum pyc gene. The cloned pyc gene was expressed in $C$. glutamicum, as cells harbouring the gene on plasmid showed four- to fivefold higher specific PCX activities when compared to the wild-type (WT). Moreover, increased PCx protein levels in the pyc-plasmidcarrying strain were readily detected after SDS-PAGE of cell-free extracts. DNA sequence analysis of the pyc gene, including its $5^{\prime}$ and $3^{\prime}$ flanking regions, and N-terminal sequencing of the pyc gene product predicts a PCX polypeptide of 1140 amino acids with an $M_{r}$ of 123070 . The amino acid sequence of this polypeptide shows between $62 \%$ and $45 \%$ identity when compared to PCx enzymes from other organisms. Transcriptional analyses revealed that the pyc gene from C. glutamicum is monocistronic ( $3.5 \mathrm{~kb}$ mRNA) and that its transcription is initiated at an $A$ residue 55 bp upstream of the translational start. Inactivation of the chromosomal pyc gene in C. glutamicum WT led to the absence of PCx activity and to negligible growth on lactate, indicating that $\mathrm{PCx}$ is essential for growth on this carbon source. Inactivation of both the PCx gene and the PEPCX gene in C. glutamicum led additionally to the inability to grow on glucose, indicating that no further anaplerotic enzymes for growth on carbohydrates exist in this organism.

Keywords: Corynebacterium glutamicum, pyruvate carboxylase, pyc gene, anaplerotic reactions, phosphoenolpyruvate carboxylase

\section{INTRODUCTION}

Pyruvate carboxylase (PCx) [pyruvate: carbon dioxide ligase (ADP-forming), EC 6.4.1.1] is a biotin-con-

† Present address: Department of Plant and Microbial Biology, University of California, Berkeley, CA 94705, USA.

‡Present address: Abteilung für Angewandte Mikrobiologie, Universităt Ulm, D-89069 Ulm, Germany.

Abbreviations: $A C$, accession number; $P C x$, pyruvate carboxylase; $P E P$, phosphoenolpyruvate; PEPCX, PEP carboxylase; TCA, tricarboxylic acid; WT, wild-type.

The EMBL accession number for the sequence reported in this paper is Y09548. taining enzyme which fulfils an important anaplerotic function in many organisms (for a review see Scrutton \& Young, 1972). The enzyme catalyses the carboxylation of pyruvate to form oxaloacetate in two steps:

Enzyme-biotin $+\mathrm{ATP}+\mathrm{HCO}_{3}^{-} \stackrel{\mathrm{Mg}^{2+}}{\rightleftharpoons}$ Enzyme-biotin-

$$
\mathrm{CO}_{2}^{-}+\mathrm{ADP}+\mathrm{P}_{\mathrm{i}}(1)
$$

Enzyme-biotin- $\mathrm{CO}_{2}^{-}+$pyruvate $\rightarrow$ Enzyme-biotin

$$
\text { +oxaloacetate }
$$

In the metabolism of carbohydrates, this two-step reaction is used for continuous replenishment of the 
Table 1. Bacterial strains and plasmids

\begin{tabular}{|c|c|c|}
\hline Strain/plasmid & Relevant characteristics* & Source/reference \\
\hline \multicolumn{3}{|l|}{ Strains } \\
\hline E. coli $\mathrm{DH} 5 \alpha$ & supE44 bsdR17 recA1 endA1 gyrA96 thi-1 relA1 & Hanahan (1985) \\
\hline E. coli $\mathrm{S} 17-1$ & Mobilizing donor strain & Simon et al. (1983) \\
\hline C. glutamicum WT & Wild-type strain ATCC 13032 & American Type Culture Collection \\
\hline C. glutamicum WT $\Delta \mathrm{pyc}$ & Defined mutant of the WT strain, PCx-negative & This work \\
\hline C. glutamicum WT $\Delta \mathrm{pyc} \Delta \mathrm{ppc}$ & $\begin{array}{l}\text { Defined double mutant of the WT, PCx- and } \\
\text { PEPCx-negative }\end{array}$ & This work \\
\hline \multicolumn{3}{|l|}{ Cosmids/plasmids } \\
\hline pHC79-based gene library & $\begin{array}{l}\text { C. glutamicum WT chromosomal DNA cloned in } \\
\text { cosmid pHC79 }\end{array}$ & Börmann et al. (1992) \\
\hline pHC79-1 & $\begin{array}{l}\text { Recombinant pHC79 cosmid containing a } 43 \mathrm{~kb} \\
\text { chromosomal Sau3A fragment from C. glutamicum }\end{array}$ & This work \\
\hline pUC18 & $\mathrm{Ap}^{\mathrm{R}}$ & Vieira \& Messing (1982) \\
\hline pUCpyc & $\begin{array}{l}\text { pUC18 containing a } 17 \mathrm{~kb} \text { HindIII fragment from } \\
\text { pHC79-1 }\end{array}$ & This work \\
\hline pGEM-T & $\begin{array}{l}\text { PCR cloning and transcription vector carrying the } \\
\text { T7 and SP6 promoters, } \mathrm{Ap}^{\mathrm{R}}\end{array}$ & Promega \\
\hline pK19mobsacB & Mobilizable vector, oriT $s a c B \mathrm{Km}^{\mathrm{R}}$ & Schäfer et al. (1994) \\
\hline pK19mobsacB $\Delta$ pyc & $\begin{array}{l}\mathrm{pK} 19 \mathrm{mobsacB} \text { containing the } 1 \mathrm{~kb} \text { fragment of the } \\
\text { deleted } p y c \text { gene }\end{array}$ & This work \\
\hline pEKO & E. coli-C. glutamicum shuttle vector, $\mathrm{Km}^{\mathrm{R}}$ & Eikmanns et al. (1991a) \\
\hline pEK0pyc & $\begin{array}{l}\text { pEK0 containing a } 6.2 \mathrm{~kb} S c a \mathrm{I}-S s p \mathrm{I} \text { fragment from } \\
\text { pUCpyc }\end{array}$ & This work \\
\hline
\end{tabular}

${ }^{*} \mathrm{Ap}^{\mathrm{R}}$, ampicillin resistance; $\mathrm{Km}^{\mathrm{R}}$, kanamycin resistance.

tricarboxylic acid (TCA) cycle for anabolic purposes, such as amino acid synthesis. Whereas PCx plays the major anaplerotic role in vertebrate tissues, especially in liver and kidney (Kornberg, 1966; Scrutton \& Young, 1972; Jitrapakdee et al., 1996) and in yeast (Ruiz-Amil et al., 1965; Stucka et al., 1991), only a few prokaryotes, e.g. some Bacillus strains and Rhodobacter capsulatus, use PCx as the sole anaplerotic enzyme (Cazzulo et al., 1970; Diesterhaft \& Freese, 1973; Sundaram, 1973; Modak \& Kelly, 1995). In many bacteria, e.g. enteric bacteria, cyanobacteria and streptomycetes, another oxaloacetate-forming enzyme, phosphoenolpyruvate carboxylase (PEPCx), is the only enzyme used for replenishing the TCA cycle during growth on glucose (Chao \& Liao, 1993; Owttrim \& Coleman, 1986; Dekleva \& Strohl, 1988). In some other bacteria, such as Pseudomonas citronellolis, P. fluorescens, Azotobacter vinelandii and Rhizobium etli, both PCX and PEPCX have been detected (Higa et al., 1976; O'Brien et al., 1977; Liao \& Atkinson, 1971; Scrutton \& Taylor, 1974; Dunn et al., 1996). However, so far the physiological role of the one anaplerotic enzyme or the other in these bacteria has not been studied in detail.

The Gram-positive, aerobic and biotin-auxotrophic Corynebacterium glutamicum is widely used in the industrial production of amino acids, particularly Lglutamate and L-lysine (Liebl, 1991; Eikmanns et al., 1993). Due to their importance in amino acid pro- duction, the anaplerotic reactions in this organism and in the subspecies C. glutamicum subsp. flavum and subsp. lactofermentum have been intensively studied. Ozaki \& Shiio (1969) and Mori \& Shiio (1985a,b) purified a PEPCx from C. glutamicum subsp. flavum and showed that the enzyme is inhibited by aspartate and 2-oxoglutarate and activated by acetyl-CoA and fructose-1,6-bisphosphate. These properties, as well as carbon flux studies, suggested that PEPCx is the major if not the only anaplerotic enzyme for growth and amino acid production on glucose as the sole carbon source (Kinoshita, 1985; Liebl, 1991, Vallino \& Stephanopoulos, 1993). However, recently it was shown that defined PEPCx-deficient mutants of C. glutamicum exhibit the same growth behaviour and the same lysine production capability as the PEPCx-positive parental strains (PetersWendisch et al., 1993; Gubler et al., 1994). These results indicated the presence of another anaplerotic enzyme in C. glutamicum apart from PEPCx. In fact, we have been able to detect PCx activity in permeabilized cells of $C$. glutamicum (Peters-Wendisch et al., 1997). The characterization of this activity revealed that the enzyme is effectively inhibited by AMP, ADP and acetyl-CoA. In this communication we describe the isolation and sequence analysis of the PCx gene $p y c$ of $C$. glutamicum as well as its transcriptional organization and its expression. Furthermore, to clarify the physiological role of PCx and PEPCx in C. glutamicum, we constructed and characterized a defined PCx-negative mu- 
tant and a defined PCX-/PEPCX-negative double mutant.

\section{METHODS}

Bacteria, plasmids and culture conditions. The bacterial strains and plasmids used are listed in Table 1. The minimal medium for growth of C. glutamicum has been described previously (Eikmanns et al., 1991b). Carbon sources were added to the minimal medium at final concentrations of $4 \%$ $(\mathrm{w} / \mathrm{v})$ glucose, $2 \%(\mathrm{v} / \mathrm{v})$ sodium DL-lactate or $2 \%(\mathrm{w} / \mathrm{v})$ potassium acetate. Luria-Bertani (LB) medium or $2 \times \mathrm{TY}$ broth (Sambrook et al., 1989) were used as the complex medium for Escherichia coli and C. glutamicum. When appropriate, ampicillin $\left(50 \mu \mathrm{g} \mathrm{ml}^{-1}\right)$ or kanamycin $\left(50 \mu \mathrm{g} \mathrm{ml}^{-1}\right)$ was added to the medium. C. glutamicum cells were grown aerobically as $60 \mathrm{ml}$ cultures in $500 \mathrm{ml}$ baffled Erlenmeyer flasks at $30^{\circ} \mathrm{C}$; E. coli cells were grown under the same conditions at $37^{\circ} \mathrm{C}$. Growth was measured as increase in $\mathrm{OD}_{600}$.

DNA preparation, transformation and conjugation. Plasmids from E. coli were isolated as described by Birnboim (1983); those from C. glutamicum were isolated by the same method with prior incubation $\left(1 \mathrm{~h}, 37^{\circ} \mathrm{C}\right)$ of the cells with lysozyme $\left(15 \mathrm{mg} \mathrm{m}^{-1}\right)$. Chromosomal DNA from C. glutamicum was isolated as described previously (Eikmanns et al., 1994). E. coli was transformed by the $\mathrm{CaCl}_{2}$ method (Sambrook et al., 1989) and C. glutamicum was transformed by electroporation as described by Liebl et al. (1989). The conjugation between E. coli S17-1 and C. glutamicum was performed as described by Schäfer et al. (1990); the resulting transconjugants were selected on LB agar plates containing kanamycin $\left(25 \mu \mathrm{g} \mathrm{ml}^{-1}\right)$ and nalidixic acid $\left(50 \mu \mathrm{g} \mathrm{ml}^{-1}\right)$.

Generation of a pyc-specific PCR product. To amplify a pycspecific fragment from chromosomal C. glutamicum DNA, two PCR primers were designed according to highly conserved regions within the $\mathrm{PCx}$ enzymes from other organisms. The conserved regions were deduced from the $\mathrm{PCx}$ amino acid sequences so far known, i.e. from Saccharomyces cerevisiae (Lim et al., 1988; EMBL accession number (AC) P11154), man (Wexler et al., 1994; MacKay et al., 1994; AC U04641), mouse (Zhang et al., 1993; AC L09192), rat (Jitrapakdee et al., 1996; AC U36585); Aedes aegypti (Z. Tu \& H. H. Hagedorn, unpublished; AC L36530) and Mycobacterium tuberculosis (D. R. Smith, unpublished; AC U00024). The PCR primers chosen corresponded to the nucleotide sequence 810-831 (primer 1: $5^{\prime}$-CGCGGGCACCGTCGAGTTCCTG- $3^{\prime}$ ) and 1037-1015 (primer 2: 5'-CCACGGTGGTGATCCGGCACTG-3') of the putative pyc gene of M. tuberculosis. Using this primer pair and chromosomal DNA of C. glutamicum, a $0.2 \mathrm{~kb}$ DNA fragment was amplified by PCR performed according to the standard procedure given by Boehringer Mannheim. The PCR fragment was cloned into the SmaI restriction site of plasmid pK19mobsacB and its DNA sequence was determined. The deduced amino acid sequence was compared with the respective region of the $\mathrm{PCx}$ amino acid sequences mentioned above and an identity of up to $64 \%$ was found. On the basis of these comparisons, it was concluded that the cloned PCR fragment represented a central $0.2 \mathrm{~kb}$ fragment of the $p y c$ gene from C. glutamicum. For identification of a chromosomal C. glutamicum DNA fragment carrying the entire $p y c$ gene, the $0 \cdot 2 \mathrm{~kb}$ fragment was amplified from genomic DNA using digoxigenin-labelled dUTP instead of dTTP, thus generating a digoxigenin-labelled pyc-specific DNA probe.
DNA manipulations. Standard protocols (Sambrook et al. 1989) were used for the construction and analysis of plasmid DNA. All restriction enzymes, T4 DNA ligase, Klenow polymerase, calf intestine phosphatase and $T a q$ polymerase were obtained from Boehringer Mannheim and used as instructed. Restriction-generated fragments were separated on $0.8 \%(\mathrm{w} / \mathrm{v})$ agarose gels and isolated using the QiaexII kit (Qiagen).

DNA hybridization experiments were performed as described previously (Peters-Wendisch et al., 1993). As a hybridization probe, the terminal $493 \mathrm{bp}$ of the pyc gene (from base 3095 to 3587 in the sequence AC Y09548, deposited in the EMBL Data Library) were amplified and digoxigenin-dUTP-labelled by PCR (PCR DIG Probe Synthesis Kit from Boehringer Mannheim) using the plasmid pUCpyc as a template. The sequence of the primers used (primers 5 and 6 ) is given below.

Colony hybridization was performed according to a method of Boehringer Mannheim. E. coli cells were transformed with a pHC79-based C. glutamicum gene library and plated onto LB-agar plates. After overnight growth, the colonies were transferred onto nylon membranes (Schleicher \& Schüll) which were then gently incubated $(5 \mathrm{~min})$ in a solution of $0.5 \mathrm{M} \mathrm{NaOH}$ and $1.5 \mathrm{M} \mathrm{NaCl}$ to lyse the cells. Afterwards the membranes were neutralized $(5 \mathrm{~min})$ with $1 \mathrm{M}$ Tris $/ \mathrm{HCl}$, $1.5 \mathrm{M} \mathrm{NaCl}, \mathrm{pH} 7.5$, and washed $(5 \mathrm{~min})$ in $2 \times \mathrm{SSC}(0.3 \mathrm{M}$ $\mathrm{NaCl}, 0.03 \mathrm{M}$ sodium citrate, $\mathrm{pH}$ 7). The cross-linking of the DNA was performed by UV irradiation ( $3 \mathrm{~min}$ ) at $366 \mathrm{~nm}$. To remove the cell debris, the membranes were incubated at $50{ }^{\circ} \mathrm{C}$ for $3 \mathrm{~h}$ in $3 \times$ SSC plus $0.1 \%$ SDS. The filters were then used for hybridization as described above.

For sequence analysis of the $p y c$ gene, several overlapping subfragments of the $17 \mathrm{~kb}$ HindIII fragment in pUCpyc were isolated and ligated into pUC18. Sequencing of the fragments in pUC18 was performed by primer walking with the dideoxy chain-termination method (Sanger et al., 1977) using fluorescently labelled nucleotides. The subsequent electrophoretic analysis was performed with an automatic DNA sequencer from Applied Biosystems by MediGene (Munich). Sequence data were compiled and analysed by the HUSAR program package from EMBL.

Gene inactivation. Inactivation of the $p y c$ gene was performed by the gene replacement method of Schäfer et al. (1994). Plasmid pUCpyc was used for the construction of a truncated $p y c$ gene. Based on the sequence of the $p y c$ gene (AC Y09548 in the EMBL Data Library), four primers (primers 3, 4, 5 and 6) were designed with extensions containing a SalI (primers 3 and 6) or a Bam HI restriction site (primers 4 and 5). Primers 3 and 4 correspond to the sequence $5^{\prime}-\mathrm{AG}$ GTCGACTCACACATCTTCAACG-3' (positions 167-188 in the sequence $\mathrm{AC}$ Y09548) and 5'-CCGGATCCACAAAGATGGGGTAAG-3' (positions 665-649). Primers 5 and 6 correspond to the sequence 5 -CCGGATCCGCCAACCGAAGAGTTC-3' (positions 3095-3110) and 5'CCGTCGACTTAGGAAACGACGACG-3' (positions 35873572). Underlined nucleotides derive from the $p y c$ sequence; nucleotides in bold represent the BamHI or Sall restriction sites. The primer pairs were used to amplify a $499 \mathrm{bp}$ fragment of the $5^{\prime}$ end and a $493 \mathrm{bp}$ fragment of the $3^{\prime}$-end of the pyc gene by PCR. After restriction with SalI and BamHI, the two fragments were separately ligated into the vector pGEM-T (Promega), resulting in pGEMpycA and pGEMpycB, respectively. Afterwards, a $1.56 \mathrm{~kb} X m n \mathrm{I}-$ Bam HI fragment from vector pGEMpycA was ligated with a $2 \cdot 46 \mathrm{~kb}$ Bam HI-XmnI fragment from vector $\mathrm{pGEMpycB}$, resulting in vector 
pGEMpycAB. This vector contains the two PCR products, i.e. the $5^{\prime}$ end of the $p y c$ gene directly followed by the $3^{\prime}$ end in the same orientation as indicated in Fig. 1(b). The truncated pyc gene was then isolated as a $1 \mathrm{~kb}$ Sall fragment and ligated into the mobilizable $E$. coli vector $\mathrm{pK} 19$ mobsacB, which is nonreplicative in C. glutamicum. Applying the method described by Peters-Wendisch et al. (1996), the resulting vector pK19mobsacB $\Delta$ pyc was used to replace the intact chromosomal pyc gene in C. glutamicum WT by the truncated pyc gene. Southern blot hybridization was performed to verify the replacement at the chromosomal pyc locus (data not shown). The $p y c$ mutant was designated C. glutamicum WT $\Delta$ pyc.

Vector $\mathrm{pK} 19 \mathrm{mobsacB} \Delta \mathrm{pyc}$ was also employed to replace the intact chromosomal pyc gene in C. glutamicum KT (PetersWendisch et al., 1996), which carries a PEPCx gene (ppc) disrupted by the chloramphenicol acetyltransferase gene (cat) in its chromosome. The chromosomal rearrangement at the $p y c$ and $p p c$ loci in the resulting $p y c-p p c$ double mutant was verified by Southern blot hybridization (data not shown) and the strain was designated C. glutamicum WT $\Delta$ pyc $\Delta$ ppc.

RNA analysis. Total RNA from C. glutamicum WT was isolated according to a method described by Börmann et al. (1992). For Northern (RNA) hybridization, a pyc-antisense RNA probe was prepared using plasmid pGEMpycAB. After linearization with SphI, digoxigenin-dUTP-labelled RNA was synthesized using SP6 RNA polymerase and the RNA Labelling Kit (SP6/T7) from Boehringer Mannheim. For hybridization, $10 \mu \mathrm{g}$ total RNA from C. glutamicum WT was denatured in loading dye (Sambrook et al., 1989) for $5 \mathrm{~min}$ at $95^{\circ} \mathrm{C}$, cooled in ice water and subjected to agarose gel electrophoresis (in $17 \%, \mathrm{v} / \mathrm{v}$, formaldehyde). The sizefractionated RNA was transferred onto a nylon membrane as described for DNA blotting (see above). Hybridization to the pyc antisense RNA probe (at $46^{\circ} \mathrm{C}$, in the presence of $50 \%$ formamide), washing and detection were performed using the Nucleic Acid Detection Kit according to the instructions from Boehringer Mannheim. The size marker was the $0.24-9.5 \mathrm{~kb}$ RNA ladder from Gibco-BRL.

For primer extension experiments, 20 pmol primer (primer 7 , 5'-TTTCAACAAGAGACCGCC-3', complementary to the sequence from position 149 to 132 in the sequence $A C Y 09548$; and primer 8, 5'-CGGTTTGCTACCAAGATC-3', complementary to the sequence from position 223 to 206) was labelled by $\mathrm{T} 4$ polynucleotide kinase (10 U; Boehringer Mannheim) with $20 \mu \mathrm{Ci}(740 \mathrm{kBq})\left[\gamma^{33} \mathrm{P}\right] \mathrm{ATP}$ (Amersham) using the ThermoSequenase Kit from Amersham. Thirty micrograms of vacuum-dried RNA from C. glutamicum was

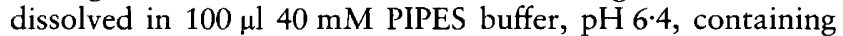
$1 \mathrm{mM}$ EDTA, $0.4 \mathrm{M} \mathrm{NaCl}$ and $80 \%(\mathrm{v} / \mathrm{v})$ formamide. After adding 4 pmol labelled primer, denaturing at $95^{\circ} \mathrm{C}(10 \mathrm{~min})$ and annealing at $45^{\circ} \mathrm{C}(16 \mathrm{~h})$, the mixture was ethanolprecipitated for $1 \mathrm{~h}$ on ice, washed once with $70 \%$ ethanol and vacuum-dried. The pellet was dissolved in $20 \mu \mathrm{l} 50 \mathrm{mM}$ Tris/ $\mathrm{HCl}$ buffer, $\mathrm{pH} 7 \cdot 6$, containing $60 \mathrm{mM} \mathrm{KCl,} 10 \mathrm{mM}$ $\mathrm{MgCl}_{2}, 500 \mu \mathrm{M}$ dATP, dCTP, dGTP and dTTP, and $40 \mathrm{U}$ RNasin. After incubation for $2 \mathrm{~min}$ at $42^{\circ} \mathrm{C}, 5 \mathrm{U}$ avian myeloblastosis virus (AMV) reverse transcriptase (Promega) was added. The mixture was incubated for $2 \mathrm{~h}$ at $42^{\circ} \mathrm{C}$ and the reaction was stopped by adding $1 \mu \mathrm{l} 0.5 \mathrm{mM}$ EDTA, pH $8 \cdot 0$. RNA was subsequently removed by incubation with RNase A $\left(0.1 \mathrm{mg} \mathrm{ml}^{-1}\right)$ for $30 \mathrm{~min}$ at $37^{\circ} \mathrm{C}$. After ethanol precipitation and vacuum drying, the primer extension product was dissolved in $3 \mu \mathrm{l}$ TE buffer plus $3 \mu \mathrm{l}$ formamide $(80 \%$, $\mathrm{v} / \mathrm{v}$ ) containing $10 \mathrm{mM}$ EDTA, $0 \cdot 1 \%$ xylene cyanole and $0.1 \%$ bromphenol blue. Two microlitres of this mixture was denatured for $5 \mathrm{~min}$ at $95^{\circ} \mathrm{C}$ and loaded onto a $6 \%(\mathrm{w} / \mathrm{v})$ polyacrylamide gel. For exact localization of the transcriptional start site, sequencing reactions using vector pUC18 carrying the $5^{\prime}$ region of the $p y c$ gene on a $1.6 \mathrm{~kb}$ ClaI fragment and the primers 3 and 4 were co-electrophoresed.

Enzyme assays. PCx activity was determined in permeabilized cells of C. glutamicum using the glutamate-oxaloacetatetransaminase-coupled discontinuous assay described previously (Peters-Wendisch et al., 1997). The aspartate formed was quantified by reversed-phase HPLC.

PEPCX activity was measured photometrically using a malate dehydrogenase coupled assay as described by Peters-Wendisch et al. (1993).

Detection of biotinylated proteins. To detect biotinylated proteins in C. glutamicum, crude extracts of different strains were separated by SDS-PAGE $(7.5 \%, w / v$ acrylamide). Proteins containing biotin were detected with a streptavidinalkaline phosphatase conjugate (Boehringer Mannheim) as described by Peters-Wendisch et al. (1997), except that the detection and colour reaction were performed directly in the gel.

$\mathrm{N}$-terminal sequence analysis. To determine the $\mathrm{N}$-terminal amino acid sequence of $\mathrm{PCx}$, the protein was isolated by avidin-affinity chromatography using a monomeric avidin resin (SoftLink Soft Release Avidin Resin, Promega). For this purpose, C. glutamicum WT(pEK0pyc) was cultivated in 11 minimal medium with lactate as carbon source and $20 \mathrm{mg}$ biotin $1^{-1}$. Exponentially growing cells were harvested, washed twice in $50 \mathrm{mM}$ Tris $/ \mathrm{HCl}, 50 \mathrm{mM} \mathrm{NaCl}, \mathrm{pH} 6.3$, and resuspended in HEPES/glycerol buffer (100 mM HEPES, pH $7 \cdot 3,20 \%, \mathrm{w} / \mathrm{v}$, glycerol $)$. After sonication, the cell debris was removed by centrifugation at $13000 \mathrm{~g}$ and $4{ }^{\circ} \mathrm{C}$. Crude extract $(10 \mathrm{ml}, 36 \mathrm{mg}$ total protein) was loaded onto a column with $5 \mathrm{ml}$ bed volume of avidin resin which was prepared as described by Promega and equilibrated with HEPES/glycerol

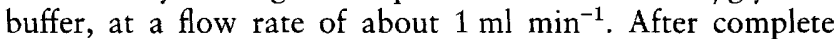
saturation of the resin with crude extract, the flow was stopped for $14 \mathrm{~h}$. Afterwards, the column was washed with $50 \mathrm{ml}$ HEPES/glycerol buffer and then the biotinylated proteins were eluted with $15 \mathrm{ml} \mathrm{HEPES/glycerol} \mathrm{buffer} \mathrm{containing}$ $5 \mathrm{mM}$ biotin and $1 \mathrm{mM}$ Pefabloc (Boehringer Mannheim). Two $4 \mathrm{ml}$ fractions were collected and concentrated threefold under vacuum. After diluting the samples with 1 vol. Laemmli buffer (Laemmli, 1970), the biotinylated proteins were sizefractionated by SDS-PAGE $(7.5 \%, \mathrm{w} / \mathrm{v}$, acrylamide), blotted onto a polyvinylidene difluoride membrane (Millipore) using a Fast Blot 33 semidry transfer cell from Biometra and stained with amido black (Sigma). The $123 \mathrm{kDa}$ band corresponding to the $\mathrm{PCx}$ was subjected to $\mathrm{N}$-terminal sequencing by the method of Edman \& Begg (1967) using a Knauer sequencer 27413.

\section{RESULTS}

\section{Isolation of the pyc gene from C. glutamicum}

To isolate the $p y c$ gene from C. glutamicum, a pHC79based cosmid gene library (Börmann et al., 1992) was transformed into E. coli $\mathrm{DH} 5 \alpha$. Approximately $10^{4}$ transformants were analysed by colony hybridization using a pyc-specific, digoxigenin-labelled PCR fragment (see Methods) as a probe. From the colonies tested, 20 hybridized to the $p y c$ probe; one of these clones was 
(a)

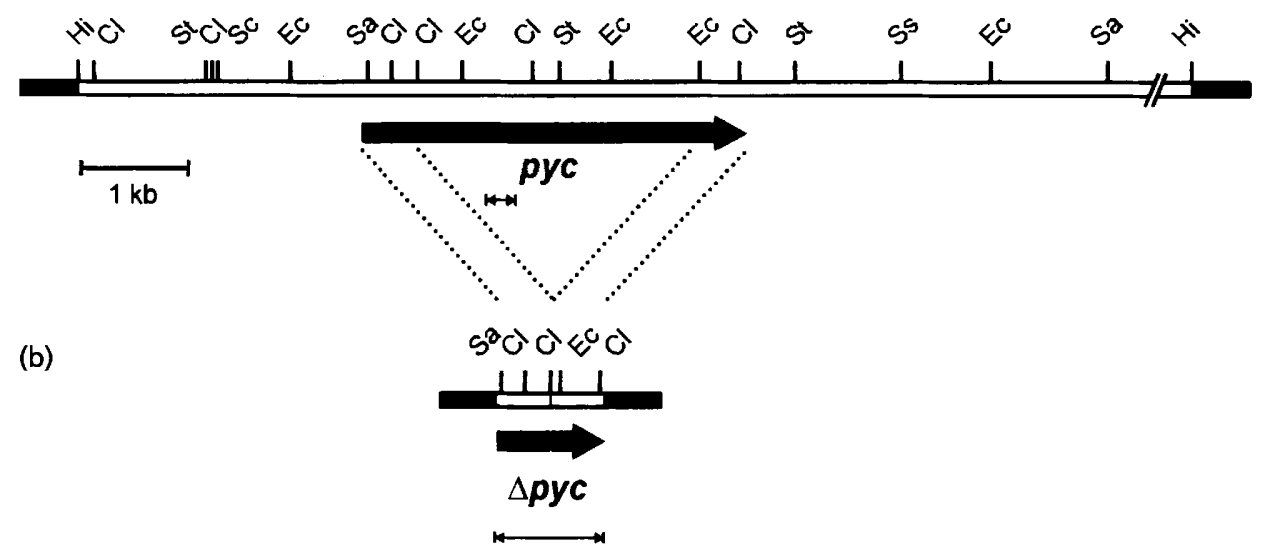

Fig. 1. Restriction map of the $17 \mathrm{~kb} \mathrm{C.} \mathrm{glutamicum} \mathrm{chromosomal} \mathrm{Hindlll} \mathrm{fragment} \mathrm{carrying} \mathrm{the} \mathrm{pyc} \mathrm{gene} \mathrm{(a)} \mathrm{and} \mathrm{of} \mathrm{the}$ truncated $1 \mathrm{~kb} \triangle$ pyc fragment (b) flanked by vector DNA. The ORF of the pyc gene is indicated by a black arrow. The double-headed arrow in (a) represents the $200 \mathrm{bp} \mathrm{PCR}$ fragment used as a probe for identification of the pyc gene; the double-headed arrow in (b) represents the antisense RNA probe used for Northern hybridization. $\mathrm{Cl}, \mathrm{Clal} ; \mathrm{EC}, \mathrm{EcoRI} ; \mathrm{Hi}$, HindIII; Sa, Sall; Sc, Scal; Ss, Sspl; St, Stul.

analysed further. It harboured cosmid pHC79-1, which contained an insert of about $43 \mathrm{~kb}$. Restriction analysis of this cosmid and hybridization with the pyc-specific probe revealed signals of about $17 \mathrm{~kb}$ after restriction with HindIII, of $6.7 \mathrm{~kb}$ after restriction with Sall and of $1.35 \mathrm{~kb}$ after restriction with EcoRI. The $17 \mathrm{~kb}$ HindIII fragment was cloned into vector pUC18, resulting in plasmid pUCpyc. The restriction map of this fragment is shown in Fig. 1.

\section{DNA sequence analysis of the pyc gene}

From pUCpyc, the $1.35 \mathrm{~kb}$ EcoRI fragment hybridizing to the $p y c$-specific probe was subcloned for sequencing. The nucleotide sequence analysis of this fragment revealed a continuous open reading frame (ORF) of $1353 \mathrm{bp}$ corresponding to a sequence of 451 amino acids. Comparison of the deduced amino acid sequence with that of the PCx from M. tuberculosis revealed $60 \%$ identity to an internal region. Thus, it could be concluded that the cloned $17 \mathrm{~kb}$ HindIII fragment in fact contains the $p y c$ gene from C. glutamicum. The $0.85 \mathrm{~kb}$ Sall-EcoRI fragment located upstream of the $1.35 \mathrm{~kb}$ EcoRI fragment (see Fig. 1) and the $1.6 \mathrm{~kb}$ EcoRIEcoRI-StuI fragment located downstream of it were isolated from pUCpyc and ligated into the vector pUC18. Sequence analysis of these fragments revealed one large ORF of 1139 codons beginning at the start of the $0.85 \mathrm{~kb}$ Sall-EcoRI fragment. To obtain information about the $5^{\prime}$ region of the $p y c$ gene, a $1.6 \mathrm{~kb} \mathrm{ClaI}$ fragment partially overlapping the SalI-EcoRI fragment (see Fig. 1) was subcloned and the terminal $381 \mathrm{bp}$ containing the ClaI and SalI restriction sites were sequenced. The nucleotide sequence assembled from all sequence reactions performed is deposited in the EMBL Data Library (AC Y09548). An ORF extending from nucleotide 108 to 3584 was observed. The first potential translational start codon in this ORF is a GTG in position 114. A second in-frame GTG codon at position 165 also represents a possible translational initiation site. All other potential translation start sites within the ORF are located downstream of regions which display a significant degree of identity to $p y c$ gene products of other organisms (see below). Downstream of the $p y c$ gene, at positions 3598-3639 in the sequence AC Y09548, a potential rho-independent termination structure was found. According to the rules of Tinoco et al. (1973), this palindromic structure should be capable of forming a stem-loop with a $\Delta G \quad\left(25^{\circ} \mathrm{C}\right)$ of $-37 \mathrm{kcal}^{\mathrm{mol}^{-1}}$ $\left(-155 \cdot 4 \mathrm{~kJ} \mathrm{~mol}^{-1}\right)$.

\section{$\mathrm{N}$-terminal sequence analysis}

As indicated above, two possible translational start sites were found (the GTG codons at positions 114 and 165 in the sequence AC Y09548). To identify the actual translational initiation site, the $\mathrm{N}$-terminal amino acid sequence of the $\mathrm{PCx}$ protein was determined. For this purpose, the enzyme was isolated from crude extract of strain C. glutamicum WT(pEK0pyc), which carries the $p y c$ gene on plasmid pEK0 (see below), by using avidinaffinity chromatography. This technique allows the isolation of biotin-containing proteins such as $\mathrm{PCx}$ (Thampy et al., 1988). The N-terminal amino acid sequence of the C. glutamicum PCx was X-T-H-T-S-XT-L-P-A (X representing amino acids which could not be unequivocally identified) and thus corresponds to the sequence S-T-H-T-S-S-T-L-P-A deduced from the nucleotide sequence of the $p y c$ gene starting at position 165 in the sequence AC Y09548. The missing initial methionine might indicate that it is removed by processing. The start codon is preceded by a typical ribosome-binding site (GAAAGGAA), although the spacing of $14 \mathrm{bp}$ between the translation start site and 


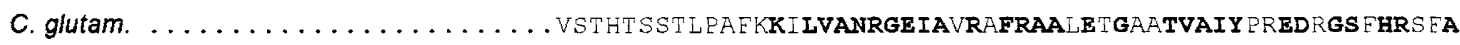

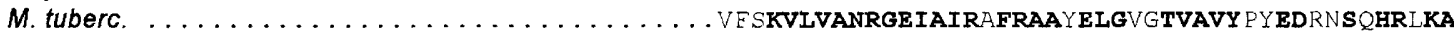

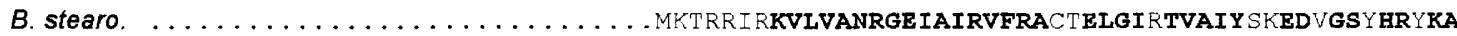

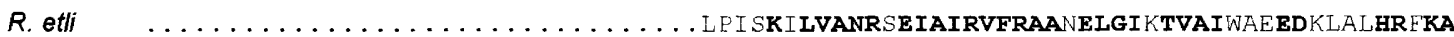
human MLKERTVHGGLRLLGIRRT STAPAAS PNVRRLEYKPIKKVMVANRGE IAIRVFRACT ELGIRTVAIYSEQDTGQMHRQKA consensus $K . * V A N R \star E I A * R, F R A . E \star G, T V A \star \star \star D . H R \star A$

C. glutam. SEA...... VRIGTEGSPVKAYLDIDEI IGAAKKVKADAIY PGYGFLSENAQLARECAENGI TFIGPT PEVLDLT GDKSR M. tuberc. DESY. . . . QIGDIGHPVHAYLSVDEIVATARRAGADAIYPGYGFLSENPDLAAACAAAGI SFVGPSAEVLELAGNKSR B. stearo. DEAYLVGEGKK...... PIEAYLDIEGIIEIAKAHDVDAI HPGYGF SENI QFAKRCREEGI IF FGPNENHLDMEGDKVK $R$. etli DESYQVGRGPHLARDLGPIESYLSIDEVIRVAKLSGADAIHPGYGLLSESPEFVDACNKAGI IFIGPKADTMRQLGNRVA human DEAYLIGRG. . . . . LAPVQAYLHI PDI I KVAKENNVDAVHPGYGFLSERADFAQACQDAGVRFIGPS EEVVRKMGDKVE

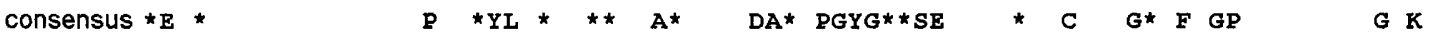

C. glutam. AVTAAKKAGLPVL. AEST PSKNI DEIVKSAEGQTYPI EVKAVAGGGGRGMREVASPDELRKLATEASREAEAAFGDGAVY $M$. tuberc. AIAAAREAGLPVLMSS. APSASVDEILSVAAGMPEPLFVKAVAGGGGRGMRRVGDIAALPEAIEAASREAESAFGDPTVY B. stearo. ARHAAVNAGI PVI PGSDGPVDGLEDVVAFAEAHGYPI I IKAALGGGGRGMRFVRSKSEVKEAFERAKSEAKAAFGSDEVY $\boldsymbol{R}$. etlj ARNLAISVGVPVVPATEPL PDDMAEVAKMAAAIGY PVMLKASWGGGGRGMRVI RSEADLAKEVTEAKREAMAAFGKDEVY human ARAIAIAAGVPVVPGTDAPITSLHAHEESNTYGEPII ERAAYGGGGRGMRVVHSYEELEENYTRAYSEALAAFGNGALE

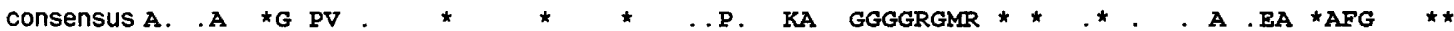

C. glutam. VERAVINPQHI EVQILGDHTGEVVHLYERDCSLQRRHQKVVEIAPAQHLDPELRDRICADAVKFCRSIGYQGAGTVEFLV $M$. tuberc. LEQAVINPRHI EVQILADNLGDVI HLYERDCSVQRRHQKVI E LAPAPHLDAELRY KMCVDAVA EARH IGY SCAGTVEFLI B. stearo. VEKLI ENPKHIEVQILGDYEGNIVHLYERDCSVQRRHQKVVEVAPSVSLSDELRQRICEAAVQLMRSVGYVNAGTVEFLV $R$. etli LEKLVERARHVESQILGDTHGNVVHL EERDCSVQRRNQKVVERAPAPYLSEAQRQE LAAYSLKIAGATNY IGAGTVEYLM human VEKEIEKPRHI EVQILGDQYGN I LHLYERDCS IQRRHQKVVE IAPAAHLD PQLRTRLT SDSVKLAKQVGYENAGTVEFLV

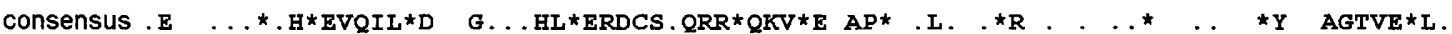

C. glutam. DEKGNHV. FIEMNPRIQVEHTVTEEVTEVDLVKAQMRLAAGATLKELGLT . . QDKIKTHGAALQCRITTEDPNNGFRPD $M$. tuberc. DERGE. YVFIEMNPRVQVEHTVTEEITDVDLVASQLRIAAGETLEQLGL . . ROEDIAEHGAAIQCRITTEDPANGFRPT B. stearo. S. . GDE FYFIEVNPRIQVEHT I TEMITGIDIVQSQI LIADGCSIH SHEVGI PKQEDIRINGYAIQSRVTTEDPLNNFMPD $R$. etti DADTGKEYFIEVNPRIQVEHTVTEVVTGIDIVKAQIHI LDGAAI GT PQSGV PNQEDIRLNGHAIQCRVTTEDPE HNF I PD human DRH. GKHYFIEVNSRLQVEHTVTEEITDVDLVHAQIHVAEGRSLPDLGL . . RQENIRINGCAIQCRVTTEDPARSFQPD

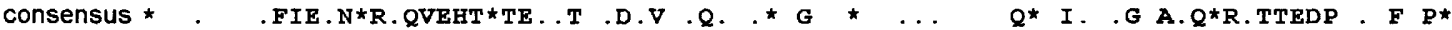

C. glutam. TGT ITAYRS PGGAGVRLDGAAQLGGE. ITAHFDSMLVKMTCRGSDFETAVARAQRALAEFTVSGVATNIGFLRALIREED $\boldsymbol{M}$. tuberc. RAGSARCDP PAVPVSAWTAAPTWRRNQPVLRLHAGQADLS . GRDLPTAVSRARRAIAEFRIRGVSTNI PELQAVLDDPD B. stearo. TGKIMAYRSGGGFGVRLDAGNGFQGAVIT PYYDSLLVKLSTWALT FEQAARKMLRNLRTFRIRVEKTNI PFLENVVQHPK $R$. etli YGRITAYRSASGFGIRLDGGTSYSGAIITRYYDELLVKVTAWA ENPLEAISRMDRAIREFRIRGVATNLTFLEAIIGHPK human TGRIEVERSGEGMGIRLDNASAEQGAVIS PHYDSLLVKVIAHGKDHPTAATKMSRALAEFRVRGVKTNIAFLQNVLNNQQ

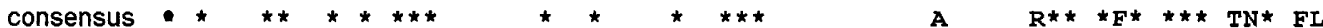

C. glutam. FTSKR IATGFIADHPHLLQA PPADDEQGRILDYLADVTVNKPHGVRPKD . . VAAPIDKLPNIKDLPLPRGSRDRLKQLG $M$. tuberc. FRAGRVTTSFIDERPQLLTARASADRGTKILNELADVTVNNPYGSR. . PSTIYPDDKL PDLDLRAAPPAGSKQRLVKLG B. stearo. FLSGEYDTSEIDTT PELFVEPRRKDRGTKMLTYIGTVTVNGEPGIGKKKK PVEDKPR. L PKLSEAE PIPAGTKQILDKHG $R$. etli FRDNSYTTRFIDTT PELFQQVKRQDRATKLLTYLADVTVNGHPEAKDRPKPLENAAR PVVPYANGNGVKDGTKQLLDTLG human FLAGTVDTQFIDENPELFQLRPAQNRAQKLLHYLGHVMVNG. PTTPI PVKASPSPTDPVVPAVPIGPPPAGERDILLREG

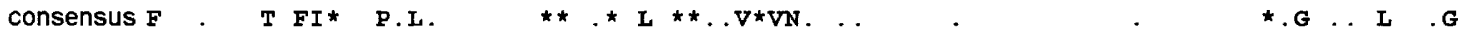

C. glutam. PAAFARDLREQDALAVTDTTFRDAHOSLIATRVRS FALKPAAEAVAKLT PELLSVEAWGGATYDVAMRFL FEDPWDRLDE M. tuberc. PEGFARWLRE SAAVGVTDTTFRDAHQSLIATRVRT SGLSRVAPY LARTMPQLLSVECWGGATYDVALRFLKEDPWERLAT B. stearo. PEGLVRWI $Q E Q P R V L L T D T T F R D A H Q S L L A T R V R T V D L V R A A E P S A R L L P N L F$ SLEMWGGATFDVAYRFL KED PWDRL $L K$ $R$. etli PKKFGEWMRNEKRVLLTDTTMRDGHQSLIATRMRTYDIARIAGTYSHALPNLLSLECWGGATFDVSMRFITEDPWERLAL human PEGFARAVRNH PGLLLMDTTFRDAHQSLIATRVRT HDLKKIAPYVAHNESKLFSMENWGGATFDVAMRFL YECPWRRLQE

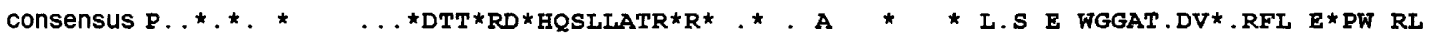

C. glutam. LREAMPNVNIQMLLRGRNTVGYT PYPDSVCRAFVKEAASSGVDIFRIFDAINDVSQMRPAIDAVLETNTAVAEVAMAYSG M. tuberc. LRAAMPNI CLQMLLRGRNTVGYTPYPEIVT SAFVQEATATGIDIFRIFDALNNIESMRPAIDAVRETGSAIAEVAMCYTG B. stearo. LRDA PNVL EQMLLRSANAVGY KNY PDNVIREFVEKSAHAGI HVFRI FD SLNWVKGMTVAIDAV. RQSGKIAEAAICYTG $R$. etli IREGAPNLLLQMLLRGANGVGYTNYPDNVVKYFVRQAAKGGIDLFRVFDCLNWVENMRVSMDAI. AEENKLCEAAICYTG human IRELI PNI PEQMLLRGANAVGYTNY PDNVVEKFCEVAKENGMDVFRVFDSLNYLPNMLLGMEAA. GSAGGVVEAAISYTG consensus $* R$. . PN QMLLR*.N VGY*.YP*.V F* *. G.* FR.FD LN . M. ..*A. .E.A. Y*G

C. glutam. DLSDPNEKLYTLDYYLKMAEEIVKSGAHILAIKDMAGLLRPAAVTKLVTALRREF . DLPVHVHTHDTAGGQLATY FAAAO M. tuberc. DLTDPGEQLYTLDYY LKLAEQIVDAGAHVLAIKDMAGLLRP PAAQRLVSALRSRF . DLPVHLHTHDT PGGQLASYVAAWH B. stearo. DILDPSRSKYNLDYYKALAKELEQAGAHILAIKDMAGLLKPOAAHVLI SGLKETV. DIPIYLHTHDTSGNGIYTYAKAIE $R$. etli DILNSARPKY DLKYYTNLAVELEKAGAHI IAVKDMAGLLKPAAAKVL FKALREA. TGLPIHFHTHDTSGIAAATVLAAVE human DVADPSRTKY SLQYYMGLAEELVRAGTHILCIKDMAGLLKPTACTMLVS SLRDRF PDLPLHI HTHDTSGAGVAAMLACAQ

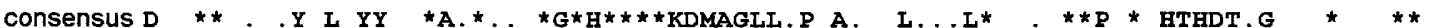

Fig. 2. For legend see facing page. 
C. glutam. AGADAVDGASAPLSGTTSQPSLSAIVAAFAHTRRDTGLSLEAVSDLEPYWEAVRGLYLPFESGTP. . GPTGRVYRHEIPG 837

M. tuberc. AGADAVDGAAAPLAGTTSQPALSSIVAAAAHTEYDTGLSLSAVCALEPYWEALRKVYAPFESG. LPGPTGRVYHHEIPG 826

B. stearo. AGVDIVDVAISSMAGLTSQPSANTLYYALEGTERAPEVDIYGLEQLARYWEDVRKEYOEFE..SGMNAPHTEVYMHEMPG 834

R. eti AGVDAVDAAMDALSGNTSQPCLGSIVEALSGSERDPGLDPAWIRRISFYWEAVRNQYAAFE. SDLKGPASEVYLHEMPG 842

human AGADVVDVAADSMSGMTSQPSMGALVACTRGTPLDTEVPMERVEDYSEYWEGARGLYAAFDCTATMKSGNSDVYENEIPG 868

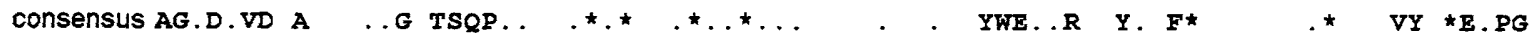

C. glutam. GQLSNLRAQATALGLADRFELIEDNYAAVNEMLGRPTKVTPSSKVVGDLALHLVGAGVDPADEAADPQKYDIPDSVIAFL 917

M. tuberc. GQLSNLRQQAIALGLGDRFEEIEEAYAGADRVLGRLVKVTPTSKVVGDLALALVGAGVSADEEASDPARFGIPESVLGFL 906

B. stearo. GQYSNLQQQAKAVGLGDRWDEVKEMYRRVNDLEGDIVKVTPSSKVVGDMALYMVQNNLTEQDIEERGETLNFPDSVVELF 914

R. etli GQFTNLKEQARSLGLET'RWHQVAQAYADANQMFGDIVKVTPSSKVVGDMALMMVSQDLTVADVVSPDREVSFPESVVSML 922

human GQYTNLHFQAHSMGLGSKFKEVKKAYVEANQMLGDLIKVTPSSKIVGDLAQFMVQNGLSRAEAEAQAEELSFPRSVVEFL 948

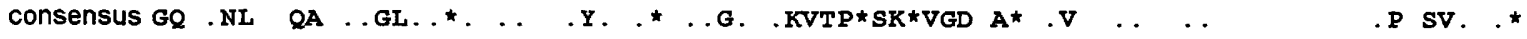

c. glutam. RGELGNPPGGWPEPLRTRALEGRSEGKAPLTEVPEEEQAHLDADDSKERR...... NSLNRILFPKPTEEFLEHRRRFG 990

M. tuberc. RGELGDPPGGWPEPLRTAALAGRGAARPTA....... QLAADDEIALSSVGAKRQATLNRLLEPSPTKEFNEHREAYG 977

B. stearo. EGYLGQPHGG PKEIQRI ILKGREPITVRPGELLEPVDEEQMKKELYDKLGREVTDEDAIAYALYPKVFLEYAETVEKYG 994

R. etli KGDLGQPPSGWPEALQKKALKGEKPYTVRPGSLLKEADLDAERKVIEKKLEREVSDEEFASYLMYPKVETDFALASDTYG 1002

human QGYIGVPHGGEPEPERSKVLKDLPRVEGRPGASLPPLDLQALEKELVDRHGEEVTPEDVLSAAMYPDVEAHFKDETATEG 1028

consensus G LG P.*G.P*.*. L.*. $\quad$. . . . . . . . . . . . . . . . . . . . . .

C. glutam. NTSALDDREFFYGLVEGRETLIRLPDVRT PLLVRLDAISE PDDKGMRNVVANVNGQIRPMRVRDRSVES.VTATAEKADS 1069

M. tuberC. DTSQLSANQFFYGLRQGEEHRVKLERGVE. LLIGLEAISE PDERGMRTVMCILNGQLRPVLVRDRSIASAVPAAE. KADR IO55

B. stearo. DVSVLDTPTFLYGMRLGEEIEVEIERGKT. IIVKLVSIGQPQADGTRVVYFELNGQPREVVIRDESIKTAVVE. HIKADR 1O72

R. etli PVSVLPTPAYFYGLADGEELFADIEKGKT. IVIVNQAVSATDSQGMVTVFFELNGQPRRIKVPDRAHGATGAAVRRKAEP 1081

human PLDSLNTRLFLQGPKIAEE FEVELERGKT. LHIKALAVSDLNRAGQRQVFFELNGQLRSILVKDTQAMKEMHFHP KALK 1106

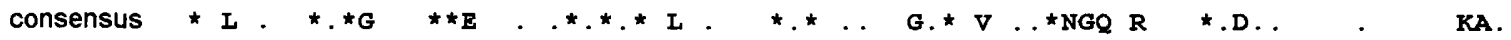

C. glutam. SNKGHVAAPFAG.VVTVTVAEGDEVKAGDAVAI IEAMKMEATITASVDGKIDRVVVPAATKVEGGDLIVVVS 1140

M. tuberc. GN PGHIAAPEAG.VVTVGVCVGERVGAGQTIATIEAMKMEAPITAPVAGTVERVAVSDTAEWRAETCWWW 124

B. stearo. TNPNHIAATMPGTVVKVLVEKGEKVDKGDHLMVTEAMKMETTVQAPEAGVVKDIYVKSGDAIQAGDLLMELSK 1145

R. etli GNAAHVGAPMPGVISRVEVSSGQAVNAGDVLVSIBAMKMETAIHAEKDGTIAEVLVKAGDQIDAKDLLAVYGG 1154

human DVKGQIGAPMPGKVI DIKVVAGAKVAKGQPLCVLSAMKMETVVTSPMEGTVRKVHVTKDMTLEGDDLILEIE 1178

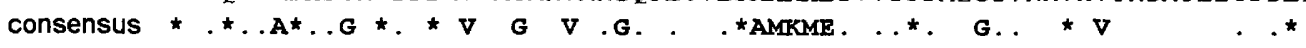

Fig. 2. Alignment of the predicted $P C x$ sequences from C. glutamicum (C. glutam.), $M$. tuberculosis (M. tuberc.; D. R. Smith, unpublished, AC U00024), B. stearothermophilus (B. stearo., Kondo et al., 1997), R. etli (Dunn et al., 1996) and human (Wexler et al., 1994). Conserved amino acids are in bold; identical amino acids in all five sequences are given as a consensus sequence below the alignment and identical amino acids in four or three sequences are marked with stars $\left({ }^{*}\right)$ and points (.), respectively.

the centre of the AGGA sequence is longer than usual (Vellanoweth \& Rabinowitz, 1992). According to the determination of the $\mathrm{N}$-terminus, the $p y c$ gene encodes a PCx polypeptide of 1140 amino acids with an $M_{\mathrm{r}}$ of 123070 .

\section{Comparison of the deduced $\mathrm{PCx}$ amino acid sequence from C. glutamicum with those from other organisms}

The amino acid sequence of the C. glutamicum PCX as deduced from the nucleotide sequence of the $p y c$ gene was aligned and compared to those of $\mathrm{PCx}$ enzymes from other sources (Fig. 2). The highest identity (62\%) was found to the putative PCx from Mycobacterium tuberculosis (Smith, 1994). Considering conservative exchanges, the similarity between the two PCx enzymes was as much as $76 \%$. A comparison of the other two prokaryotic PCx sequences identified, i.e. from Bacillus stearothermophilus (Kondo et al., 1997) and Rhizobium etli (Dunn et al., 1996), revealed $47 \%$ and $46 \%$ identical and $65 \%$ and $64 \%$ similar amino acids, respectively. About the same percentage of identical and similar amino acids was found when the C. glutamicum PCx was compared to human PCx (Wexler et al., 1994) and to all other known eukaryotic PCx enzymes (Zhang et al., 1993; Jitrapakdee et al., 1996; Z. Tu \& H. H. Hagedorn, unpublished, AC L36530; Lim et al., 1988; Stucka et al., 1991).

\section{Transcriptional analysis of the pyc gene}

Northern (RNA) hybridization experiments were performed to analyse the size of the pyc transcript. For this purpose, total RNA from C. glutamicum WT was isolated, size-fractionated, transferred onto a nylon membrane and hybridized to a $p y c$-specific digoxigenindUTP-labelled antisense RNA probe. This probe was synthesized by in vitro transcription of the $1.0 \mathrm{~kb} \Delta p y c$ insert of plasmid pGEM $\triangle$ pycAB (Fig. 1b). The hybridization revealed a signal at about $3.5 \mathrm{~kb}$ (Fig. 3a), which 


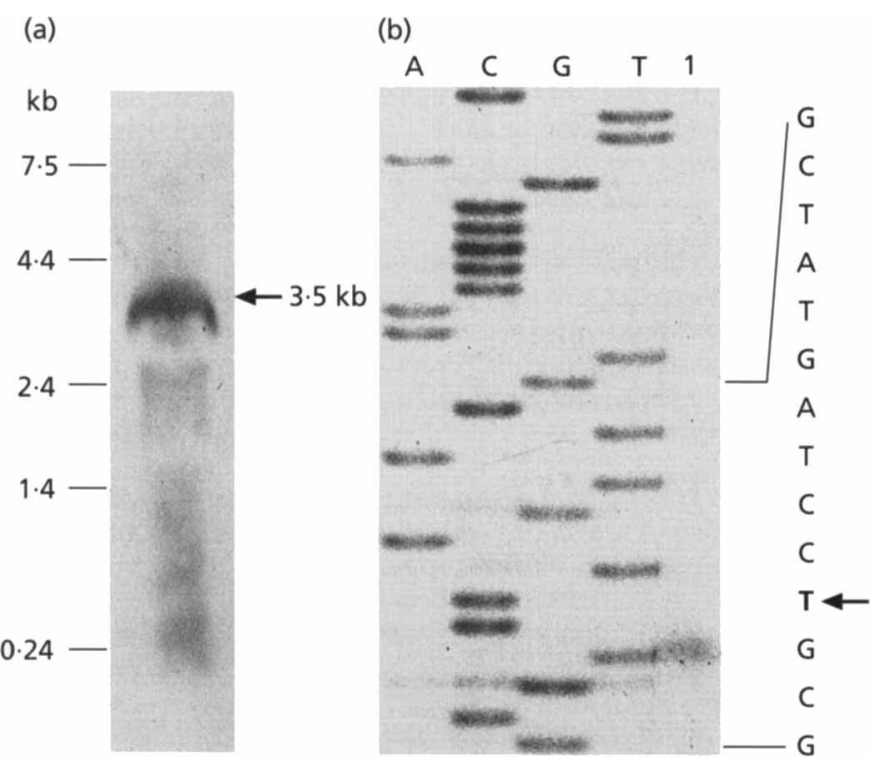

Fig. 3. Northern hybridization analysis of the pyc gene from C. glutamicum (a) and primer extension analysis of the transcriptional start site (b). RNA standards in the Northern experiment are shown on the left. The primer extension product is shown in lane 1 . Lanes $A, C, G$ and $T$ represent the sequencing reaction using the same primer as for the primer extension. The relevant DNA sequence is shown on the right. Note that the sequence represents the coding strand and is thus complementary to that shown in Fig. 2.

is approximately the size of the $p y c$ gene. Thus, the result indicates that the C. glutamicum pyc transcript is monocistronic.

To identify the transcriptional initiation site of the $C$. glutamicum $p y c$ gene, primer extension experiments were performed. Total RNA of C. glutamicum WT was isolated from cells grown on lactate minimal medium and used for reverse transcription with the different $p y c$ specific primers 7 and 8 (see Methods). With both primers, signals were obtained corresponding to the $A_{109}$ residue in in the sequence AC Y09548. The result of the primer extension experiment with primer 7 is shown in Fig. 3(b). Thus, the transcription of the C. glutamicum $p y c$ gene starts 55 nucleotides upstream of the $p y c$ translational start. The distance from this transcriptional start site to the predicted terminator structure downstream of the $p y c$ gene is $3.54 \mathrm{~kb}$, which is in complete agreement with the size of the transcript determined by Northern blot hybridization (see above).

\section{Expression of the cloned pyc gene}

To investigate whether the isolated $p y c$ gene encodes a functional PCx, the gene was cloned as a $6.2 \mathrm{~kb}$ Scal-SspI fragment into the E. coli-C. glutamicum shuttle vector $\mathrm{pEK} 0$, giving rise to the plasmid pEKOpyc. This plasmid was transformed into C. glutamicum R127-SP733, a PCx-negative mutant previously generated by chemical mutagenesis and isolated due to its inability to grow on lactate as the sole carbon source (Peters-Wendisch et al., 1997). The resulting strain R127-SP733(pEK0pyc) was able to grow on lactate, suggesting that the $p y c$ gene cloned was functional.

To test the overexpression of the $p y c$ gene in C. glutamicum, the pEK0pyc was transformed into C. glutamicum WT and crude extract of the resulting strain, C. glutamicum WT(pEK0pyc), was tested for

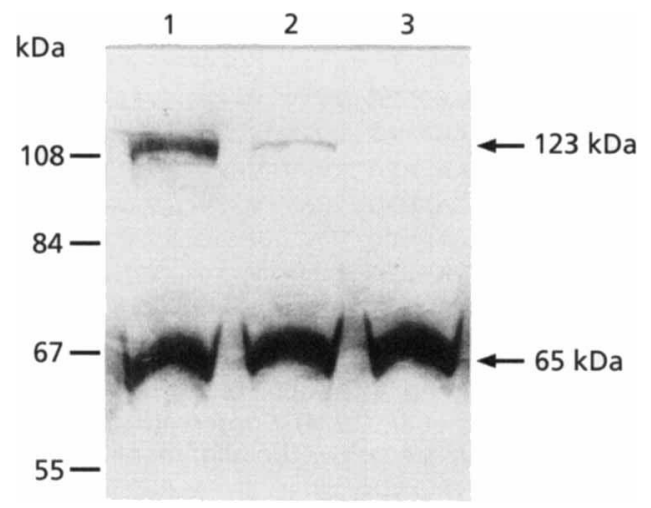

Fig. 4. Analysis of biotinylated proteins from C. glutamicum. Lanes 1, 2 and 3 represent cell-free extracts from C. glutamicum WT(pEKOpyc), WT and WT $\triangle$ pyc, respectively. Sizes of biotinylated proteins and the positions of protein molecular mass markers (Sigma) are indicated.

biotinylated proteins (Fig. 4). In extracts of C. glutamicum WT, two biotinylated proteins appeared: a $65 \mathrm{kDa}$ protein corresponding to a subunit of an acylCoA carboxylase of C. glutamicum (Jäger et al., 1996) and a $123 \mathrm{kDa}$ protein representing the $p y c$ gene product as shown by $\mathrm{N}$-terminal sequence analysis. Whereas the $65 \mathrm{kDa}$ protein was present in the same amounts in C. glutamicum WT and WT(pEK0pyc), a significantly higher amount of the $123 \mathrm{kDa}$ protein was synthesized in strain $\mathrm{WT}(\mathrm{pEK} 0 \mathrm{pyc})$ than in the original host strain WT.

The overexpression of the $p y c$ gene was also tested by enzyme analysis. PCx activity of $C$. glutamicum WT(pEK0pyc) was measured in cells grown on complex medium as well as in cells grown on minimal medium with lactate, glucose or acetate as sole carbon source. As shown in Table 2, the specific activity of the PCx in 
Table 2. Specific PCX and PEPCX activities in different strains of C. glutamicum

PCx was determined in permeabilized cells and PEPCx in crude extracts; the values are means \pm SD obtained from at least two independent cultivations by two determinations per experiment. ND, Not determined; NG, no growth.

\begin{tabular}{|c|c|c|c|c|c|}
\hline \multirow[t]{3}{*}{ Strain } & \multicolumn{4}{|c|}{ PCx $\left[\right.$ nmol $\left.\min ^{-1}(\mathrm{mg} \text { dry wt })^{-1}\right]$} & \multirow{3}{*}{$\begin{array}{c}\text { PEPCx } \\
{\left[\mathrm{nmol} \mathrm{min}^{-1}(\mathrm{mg}\right.} \\
\left.\text { protein })^{-1}\right] \\
\left(\text { complex }^{2}\right. \\
\left.\text { medium }{ }^{*}\right)\end{array}$} \\
\hline & \multicolumn{3}{|c|}{ Minimal medium } & \multirow{2}{*}{$\begin{array}{l}\text { Complex } \\
\text { medium }\end{array}$} & \\
\hline & Lactate & Glucose & Acetate & & \\
\hline WT & $37 \pm 2$ & $19 \pm 4$ & $27 \pm 7$ & $27 \pm 3$ & $69 \pm 5$ \\
\hline WT(pEK0pyc) & $152 \pm 11$ & $75 \pm 13$ & $97 \pm 4$ & $127 \pm 10$ & ND \\
\hline WT $\Delta$ pyc & NG & ND & ND & $<0.3$ & $62 \pm 4$ \\
\hline WT $\Delta \mathrm{pyc} \Delta \mathrm{ppc}$ & NG & NG & ND & $<0 \cdot 3$ & $<0 \cdot 3$ \\
\hline
\end{tabular}

* Complex medium with $0.5 \%$ lactate.

WT(pEK0pyc) was four to five times higher than in the WT strain. PCx activity was highest in cells grown on lactate and two times lower in cells grown on acetate or glucose. This regulation was also observed in the WT strain and this result thus suggests that the cloned fragment contains not only the structural $p y c$ gene but also the regulatory regions.

\section{Inactivation of the chromosomal pyc gene}

In order to obtain a defined PCx-negative mutant of $C$. glutamicum, the chromosomal pyc gene was replaced by a truncated gene. The resulting mutant $C$. glutamicum WT $\Delta$ pyc was tested for PCx activity, for formation of the $123 \mathrm{kDa}$ biotinylated protein and for growth on different media. The specific activity was measured in permeabilized cells after growth on complex medium containing lactate as a carbon source. As shown in Table 2 the mutant was devoid of any detectable PCx activity whereas PEPCx activity was measurable in the same amount as in the WT strain. Fig. 4 (lane 3) shows that the mutant was also devoid of the $123 \mathrm{kDa}$ protein. The growth experiments revealed that C. glutamicum WT $\Delta$ pyc grew almost as well as the parental strain C. glutamicum WT on minimal medium with glucose (Fig. 5a) or acetate (Fig. 5c), whereas the growth of the mutant was negligible on minimal medium containing lactate as the sole carbon source (Fig. $5 \mathrm{~b}$ ). These results indicate that the PCx in C. glutamicum is essential for growth on lactate but not for growth on glucose or acetate as the sole carbon source.

To test whether C. glutamicum possesses, apart from PCx and PEPCx, further enzymes which can fulfil the anaplerotic function during growth on glucose, a double mutant with truncated PCx and PEPCx genes was constructed and its growth behaviour analysed. This double mutant C. glutamicum WT $\Delta$ pyc $\Delta$ ppc showed neither PCx nor PEPCx activity (Table 2). The double mutant was able to grow in minimal medium containing acetate but it did not grow in medium containing lactate or glucose as the sole carbon sources (Fig. 5). These results indicate that $\mathrm{PCx}$ is an essential anaplerotic enzyme for growth on glucose in the absence of PEPCx and thus that during growth on glucose no further anaplerotic enzymes are functional in C. glutamicum.

\section{DISCUSSION}

Despite the importance of PCx in the central metabolism of many organisms, only a few genetic studies on this enzyme have been performed. So far, $p y c$ genes have been isolated, sequenced and characterized only from the eukaryotic organisms man, mouse, rat and $S$. cerevisiae, and from the prokaryotes $R$. etli and $B$. stearothermophilus (Wexler et al., 1994; Zhang et al., 1993; Jitrapakdee et al., 1996; Lim et al., 1988; Stucka et al., 1991; Dunn et al., 1996; Kondo et al., 1997). Additionally, the pyc sequences of the mosquito Aedes aegypti and of $M$. tuberculosis are available in the EMBL Data Library (Tu \& Hagedorn, 1994; Smith, 1994). We have now isolated and characterized the pyc gene of C. glutamicum. Structural analysis of the gene and the $\mathrm{N}$-terminal amino acid sequence analysis of the protein revealed a polypeptide of 1140 amino acids, corresponding to an $M_{r}$ of 123070 . With this size, the PCx of C. glutamicum is comparable to most other PCx enzymes, which were shown to be homotetramers consisting of four tetrahedrically arranged subunits with an $M_{\mathrm{r}}$ of about 120000 (Attwood, 1995). Some bacterial PCx enzymes have a different subunit structure and composition, e.g. Pseudomonas citronellolis possesses two different subunits, $\alpha$ and $\beta$, forming a native $\alpha_{4} \beta_{4}$ enzyme (Goss et al., 1981; Fuchs et al., 1988). The $\alpha$ subunit $\left(M_{\mathrm{r}} 65000\right)$ carries the biotin moiety and contains all catalytically active sites necessary for the $\mathrm{PCx}$ reaction, and the $\beta$ subunit $\left(M_{\mathrm{r}} 54000\right)$ is responsible for the conformational stability in the core of the enzyme (Goss et al., 1981).

The biotin-containing PCx enzymes belong to a family of enzymes which includes acyl-CoA carboxylases, 

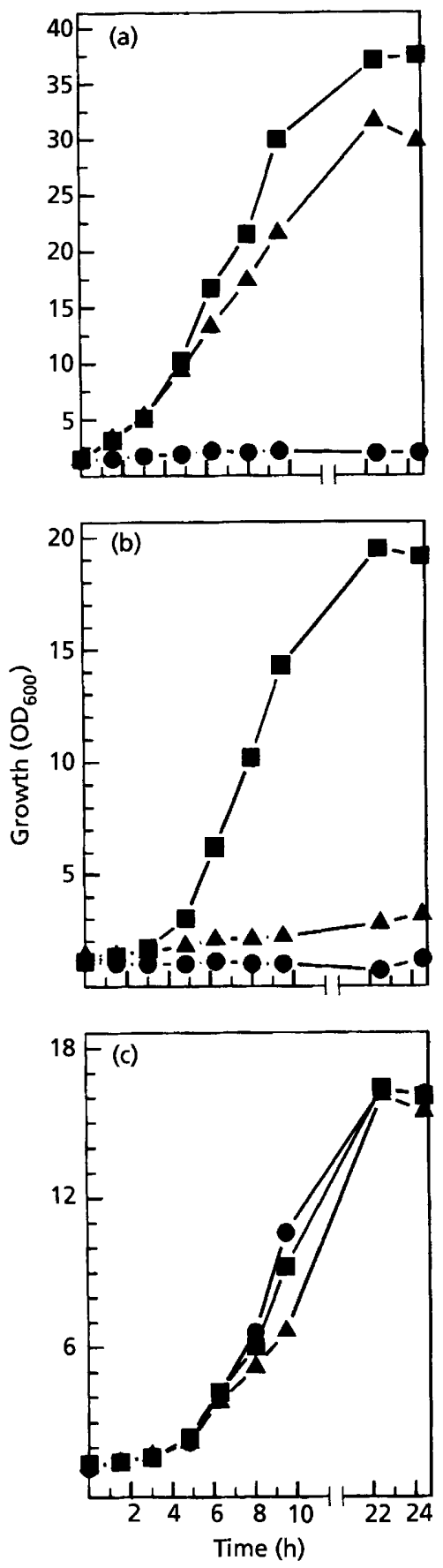

Fig. 5. Comparative growth experiments with C. g/utamicum WT (D), the pyruvate carboxylase-negative mutant WT $\Delta$ pyc ( $\boldsymbol{\Delta}$ ) and the pyruvate carboxylase- and PEP carboxylase-negative double mutant WT $\Delta \mathrm{pyc} \Delta \mathrm{ppc}(\mathbf{O})$ on glucose (a), lactate (b) and acetate (c).

oxaloacetate decarboxylases and transcarboxylases (Samols et al., 1988; Toh et al., 1993). All the enzymes of this family show a common catalytic mechanism: the carboxylation of a covalently attached biotin moiety (reaction 1; see Introduction), and transcarboxylation from the carboxy-biotin to a specific acceptor molecule (exemplified by reaction 2). These common catalytic features correspond to conserved structural and sequence motifs (Knowles, 1989; Toh et al., 1993), i.e. the biotin-carrier domain, the biotin carboxylase domain characterized by a typical ATP-binding site, and the carboxytransferase domain characterized by a specific substrate-binding site (for pyruvate in the case of $P C x$, oxaloacetate decarboxylase and transcarboxylase, and for acyl-CoA in the case of acyl-CoA carboxylases). Accordingly, a comparison of the PCx from C. glutamicum with PCx enzymes and biotin-dependent (de)carboxylases from other organisms revealed amino acid sequence motifs with a high degree of identity, especially in those regions suggested to be essential for the catalytic activity. Near the C-terminus of the C. glutamicum PCx there is the conserved sequence motif -A-M-K-M(positions 1104-1107 in Fig. 2) representing the biotinbinding site (Samols et al., 1988; Dunn et al., 1996). Biotin is covalently attached to the central lysine residue within this sequence motif (Rylatt et al., 1977). Apart from the -A-M-K-M- motif, the so-called proline hinge (position 1078 of the C. glutamicum PCx in Fig. 2), suggested to be necessary for the flexibility of the biotincarrier domain (Leon-Del-Rio \& Gravels, 1994), and three glycine residues (positions 1090, 1096 and 1117) involved in the biotinylation of the enzymes (Leon-DelRio \& Gravels, 1994) can be found in the C. glutamicum PCx. A further highly conserved amino acid sequence (GGGGRG at position 173 in Fig. 2) was found at the Nterminus of the C. glutamicum PCx. This GGGG(R/K)G motif is present in all biotin-containing (de)carboxylases and is believed to correspond to the ATP-binding site (Lim et al., 1988; Wexler et al., 1994). In the central region of the C. glutamicum PCx protein, the motif -FL-F-E-D-P-W-D-R- (positions 588-596 in Fig. 2) is found. The transcarboxylase from Propionibacterium shermanii contains a similar amino acid sequence (-F-LN-E-D-P-W-E-R-) and tryptophan fluorescence analysis showed the tryptophan within this sequence to be involved in pyruvate binding in the transcarboxylation reaction (Kumar et al., 1988). All these findings corroborate and extend the previous theory that the biotincontaining (de)carboxylases derive from a common ancestor protein and that these enzymes have retained the catalytically important motifs over a large evolutionary distance (Samols et al., 1988; Kondo et al., 1997).

The determination of the C. glutamicum pyc transcript length revealed a size of about $3.5 \mathrm{~kb}$, indicating that the gene is transcribed as a monocistronic message and is not organized as an operon. This is the first time that the genomic organization of a $p y c$ gene has been analysed in a prokaryotic organism. In addition, the transcriptional start site of the $p y c$ gene was determined and found to be located at an A residue $55 \mathrm{bp}$ in front of the translational start site. Upstream of the transcriptional start site, putative -10 and -35 regions could be found which are reasonably well-conserved in comparison to the predicted promoter consensus sequence from C. glutamicum (Pátek et al., 1996). In the -10 region 
(TACGAT) four of six bases are identical to the conserved sequence TA.aaT, whereas in the -35 region (TTGATT) three of six nucleotides are identical to the consensus hexamer ttGcca. The relatively low similarity to the consensus sequence might indicate that the $p y c$ promoter mediates a moderate expression of the $p y c$ gene and this corresponds to the relatively low amount of the PCx protein (123 kDa biotinylated protein, Fig. 4) present in cell-free extracts.

The characterization of the defined PCx-negative mutant C. glutamicum WT $\Delta$ pyc corroborates our previous hypothesis that PCx is essential as an anaplerotic enzyme for growth on lactate but not essential for growth on glucose or acetate as carbon sources (Peters-Wendisch $e t$ al., 1997). However, in comparison to the double mutant WT $\Delta$ pyc $\Delta$ ppc the single mutant WT $\Delta$ pyc, which possesses the same PEPCx activity as the WT strain (Table 2 ), showed some, albeit slow, growth on lactate. This slow growth might be due to oxaloacetate formation from pyruvate via PEP (PEP synthase and PEPCx reactions). PEP synthase activity was previously proposed to be present in some C. glutamicum strains (Vallino \& Stephanopoulos, 1993; Jetten et al., 1994; Cocaign-Bousquet \& Lindley, 1995), although, according to the results presented here, the in vivo activity of this enzyme is probably very low in our C. glutamicum strain.

In Bacillus subtilis and B. stearothermophilus, PCx is not only essential for growth on lactate but also for growth on glucose, as $\mathrm{PCx}$-negative mutants were unable to grow on either substrate as the sole carbon source (Diesterhaft \& Freese, 1973; Sundaram, 1973). In contrast to the two Bacillus species, C. glutamicum possesses PEPCx as an additional anaplerotic enzyme. As shown by the fact that the PCx-and PEPCx-negative double mutant C. glutamicum WT $\Delta \mathrm{pyc} \Delta \mathrm{ppc}$ did not grow on glucose, the ability of C. glutamicum WT $\Delta$ pyc to grow on this substrate is due to the presence of PEPCx. On the other hand, it has previously been shown by the analysis of a defined PEPCx-negative mutant of C. glutamicum that PEPCX is dispensable for growth of C. glutamicum on glucose and that this mutant possesses the same level of PCx activity as the WT strain (PetersWendisch et al., 1993, 1997), and therefore our results indicate that PCx and PEPCx can basically replace each other as the anaplerotic enzyme in this organism. However, when compared to the WT strain, the PCxnegative mutant but not the PEPCx-negative mutant showed slightly slower growth on glucose (see Fig. 5a and Peters-Wendisch et al., 1993), which might suggest a primary role of $\mathrm{PCx}$. For Rbizobium etli and $R$. tropici, both also possessing PEPCx in addition to PCx (Dunn et al., 1996), it has been shown that PCx-negative mutants grow on glucose much more slowly and have a much lower final cell yield than the parental strains (Dunn et al., 1996). These results indicate that in R. etli and $R$. tropici the PEPCx can replace the PCx only to a minor extent and thus that PCx in these organisms is the predominant anaplerotic enzyme for growth on glucose. For a pyruvate-kinase-defective mutant of C. glutami- cum, it has recently been shown by ${ }^{13} \mathrm{C}-\mathrm{NMR}$ spectroscopy that during lysine production with pyruvate and gluconate as carbon sources (a) pyruvate-carboxylating pathway(s) contribute(s) approximately $90 \%$ of the total oxaloacetate synthesis (Park et al., 1997). The extent to which the anaplerotic function during growth of C. glutamicum WT on glucose is accomplished by PCx and/or PEPCx is certainly dependent on the intracellular concentrations of the various effectors of the two enzymes [PCx is inhibited by acetyl-CoA, ADP and AMP (Peters-Wendisch et al., 1997), and PEPCx is inhibited by aspartate and activated by acetyl-CoA and fructose-1,6-bisphosphate (Mori \& Shiio, 1985a, b)]; this remains to be studied by appropriate ${ }^{13} \mathrm{C}$-labelling experiments and carbon-flux analysis.

Apart from PEPCx and PCx, further enzymes have been discussed as possibly playing an anaplerotic role during growth of C. glutamicum on glucose, i.e. PEP carboxykinase (Gubler et al., 1994), the glyoxylate cycle enzymes isocitrate lyase and malate synthase (de Hollander $e t$ al., 1994) and the malic enzyme (Cocaign-Bousquet et al., 1996). The fact that the defined PCx- and PEPCxnegative double mutant of C. glutamicum did not grow on glucose minimal medium excludes participation in replenishment of the TCA cycle by any of the other enzymes discussed as potential anaplerotic enzymes in C. glutamicum WT.

\section{ACKNOWLEDGEMENTS}

The authors are grateful to Dr B. Obermaier (MediGene) for DNA sequencing, to Professor Dr H. Tschesche (University of Bielefeld) for $\mathrm{N}$-terminal sequencing of the $123 \mathrm{kDa}$ protein, to $\mathrm{M}$. Romes for preparing the photographs, and to Dr V. Wendisch and J. Carter-Sigglow for critical reading of the manuscript. The authors also acknowledge the support for this work from grant BIO4-CT96-0145 within the 4th Framework Programme of the EC.

\section{REFERENCES}

Attwood, P. V. (1995). The structure and the mechanism of action of pyruvate carboxylase. Int J Biochem Cell Biol 27, 231-249.

Birnboim, H. C. (1983). A rapid alkaline extraction method for the isolation of plasmid DNA. Methods Enzymol 100, 243-255.

Börmann, E. R., Eikmanns, B. J. \& Sahm, H. (1992). Molecular analysis of the Corynebacterium glutamicum gdb gene encoding glutamate dehydrogenase. Mol Microbiol 6, 317-326.

Cazzulo, J. J., Sundaram, T. K. \& Kornberg, H. L. (1970). Properties and regulation of pyruvate carboxylase from Bacillus stearothermophilus. Proc R Soc Lond B 16, 1-19.

Chao, Y.-P. \& Liao, J. C. (1993). Alteration of growth yield by overexpression of phosphoenolpyruvate carboxylase and phosphoenolpyruvate carboxykinase in Escherichia coli. Appl Environ Microbiol 59, 4261-4265.

Cocaign-Bousquet, M. \& Lindley, N. D. (1995). Pyruvate overflow and carbon flux within the central metabolic pathways of Corynebacterium glutamicum during growth on lactate. Enzyme Microb Technol 17, 260-267.

Cocaign-Bousquet, M., Guyonvarch, A. \& Lindley, N. D. (1996). Growth rate-dependent modulation of carbon flux through 
central metabolism and the kinetic consequences for glucose limited chemostat cultures of Corynebacterium glutamicum. Appl Environ Microbiol 62, 429-436.

Dekleva, M. L. \& Strohl, W. R. (1988). Activity of phosphoenolpyruvate carboxylase of an anthracycline-producing streptomycete. Can J Microbiol 34, 1241-1246.

Diesterhaft, M. D. \& Freese, E. (1973). Role of pyruvate carboxylase, phosphoenolpyruvate carboxykinase, and malic enzyme during growth and sporulation of Bacillus subtilis. J Biol Chem 248, 6062-6070.

Dunn, M. F., Encarnación, S., Arafza, G., Vargas, M. C., Dávalos, A., Peralta, A., Mora, Y. \& Mora, J. (1996). Pyruvate carboxylase from Rhizobium etli: mutant characterization, nucleotide sequence, and physiological role. J Bacteriol 178, 5960-5970.

Edman, P. \& Begg, G. (1967). A protein sequenator. Eur J Biochem $1,80-91$.

Eikmanns, B. J., Kleinertz, E., Liebl, W. \& Sahm, H. (1991a). A family of Corynebacterium glutamicum/Escherichia coli shuttle vectors for cloning, controlled gene expression, and promoter probing. Gene 102, 93-98.

Eikmanns, B. J., Metzger, M., Reinscheid, D. J. \& Sahm, H. (1991b). Amplification of three threonine biosynthesis genes in Corynebacterium glutamicum and its influence on carbon flux in different strains. Appl Microbiol Biotechnol 34, 617-622.

Eikmanns, B. J., Eggeling, L. \& Sahm, H. (1993). Molecular aspects of lysine, threonine, and isoleucine biosynthesis in Corynebacterium glutamicum. Antonie Leeuwenhoek 64, 145-163.

Eikmanns, B. J., Thum-Schmitz, N., Eggeling, L., Lüdtke, K.-U. \& Sahm, H. (1994). Nucleotide sequence, expression and transcriptional analysis of the Corynebacterium glutamicum glt $A$ gene encoding citrate synthase. Microbiology 140, 1817-1828.

Fuchs, J., Johannssen, W., Rohde, M. \& Mayer, F. (1988). Pyruvate carboxylase from Pseudomonas citronellolis: shape of the enzyme, and localization of its prosthetic biotin group by electron microscopic affinity labeling. FEBS Lett 231, 102-106.

Goss, J. A., Cohen, N. D. \& Utter, M. F. (1981). Characterization of the subunit structure of pyruvate carboxylase from Pseudomonas citronellolis. J Biol Chem 256, 11819-11825.

Gubler, M., Park, S. M., Jetten, M., Stephanopoulos, G. \& Sinskey, A. J. (1994). Effects of phosphoenolpyruvate carboxylase deficiency on metabolism and lysine production in Corynebacterium glutamicum. Appl Microbiol Biotechnol 40, 857-863.

Hanahan, D. (1985). Studies on transformation of Escherichia coli with plasmids. J Mol Biol 166, 557-580.

Higa, A. l., Milrad de Forchetti, S. R. \& Cazzulo, J. J. (1976). $\mathrm{CO}_{2}$ fixing enzymes in Pseudomonas fluorescens. J Gen Microbiol $\mathbf{9 3}$, 69-74.

Hollander, J. A. de (1994). Potential metabolic limitations in lysine production by Corynebacterium glutamicum as revealed by metabolic network analysis. Appl Microbiol Biotechnol 42 508-515.

Jäger, W., Peters-Wendisch, P. G., Kalinowski, J. \& Puhler, A. (1996). A Corynebacterium glutamicum gene encoding a twodomain protein homologous to biotin carboxylases and biotin carboxyl carrier proteins. Arch Microbiol 166, 76-82.

Jetten, M. S. M., Pitoc, G. A., Follettie, M. T. \& Sinskey, A. J. (1994). Regulation of phospho(enol)-pyruvate- and oxaloacetateconverting enzymes in Corynebacterium glutamicum. Appl Microbiol Biotechnol 41, 47-52.

Jitrapakdee, S., Booker, G. W., Cassady, A. I. \& Wallace, J. C. (1996). Cloning, sequencing and expression of rat liver pyruvate carboxylase. Biochem J 316, 631-637.
Kinoshita, S. (1985). Glutamic acid bacteria. In Biology of Industrial Microorganisms, pp. 115-142. Edited by A. L. Demain \& N. A. Solomon. London: Benjamin/Cummings.

Knowles, J. R. (1989). The mechanism of biotin-dependent enzymes. Annu Rev Biochem 58, 195-221.

Kondo, H., Kazuta, Y., Saito, A. \& Fuji, K. (1997). Cloning and nucleotide sequence of Bacillus stearothermophilus pyruvate carboxylase. Gene 191, 47-50.

Kornberg, H. L. (1966). Anaplerotic sequences and their role in metabolism. In Essays in Biochemistry, vol II, pp. 1-31. Edited by P. N. Campbell \& G. D. Greville. New York: Academic Press.

Kumar, G. K., Haase, F. C., Phillips, N. F. B. \& Wood, H. G. (1988). Involvement and identification of a tryptophanyl residue at the pyruvate binding site of transcarboxylase. Biochemistry 27, 5978-5983.

Laemmli, U. K. (1970). Cleavage of structural proteins during the assembly of the head of bacteriophage T4. Nature 227, 680-685.

Leon-Del-Rio, A. \& Gravels, R. A. (1994). Sequence requirements for the biotinylation of carboxyl-terminal fragments of human propiony-CoA carboxylase $\alpha$ subunit expressed in Escherichia coli. J Biol Chem 269, 22964-22968.

Liao, C.-L. \& Atkinson, D. E. (1971). Regulation at the phosphoenolpyruvate branchpoint in Azotobacter vinelandii: phosphoenolpyruvate carboxylase. J Bacteriol 106, 31-36.

Liebl, W. (1991). The genus Corynebacterium-nonmedical. In The Prokaryotes, vol II, pp. 1157-1171. Edited by A. Balows, H. G. Trüper, M. Dworkin, W. Harder \& K.-H. Schleifer. New York: Springer.

Liebl, W., Klamer, R. \& Schleifer, K.-H. (1989). Requirement of chelating compounds for growth of Corynebacterium glutamicum in synthetic media. Appl Microbiol Biotechnol 32, 205-210.

Lim, F., Morris, C. P., Occhiodoro, F. \& Wallace, J. C. (1988), Sequence and domain structure of yeast pyruvate carboxylase. J Biol Chem 263, 11493-11497.

MacKay, N., Rigat, B., Douglas, C., Chen, H. S. \& Robinson, B. H. (1994). cDNA cloning of human kidney pyruvate carboxylase. Biochem Biophys Res Commun 202, 1009-1014.

Modak, H. V. \& Kelly, D. J. (1995). Acetyl-CoA-dependent pyruvate carboxylase from the photosynthetic bacterium $R$ hodobacter capsulatus: rapid and efficient purification using dye-ligand affinity chromatography. Microbiology 141, 2619-2628.

Mori, M. \& Shiio, I. (1985a). Purification and some properties of phosphoenolpyruvate carboxylase from Brevibacterium flavum and its aspartate-overproducing mutant. J Biochem 97, 11191128.

Mori, M. \& Shiio, I. (1985b). Synergistic inhibition of phosphoenolpyruvate carboxylase by aspartate and 2-oxoglutarate in Brevibacterium flavum. J Biochem 98, 1621-1630.

O'Brien, R. W., Chuang, D. T., Taylor, B. L. \& Utter, M. F. (1977). Novel enzymic machinery for the metabolism of oxalacetate, phosphoenolpyruvate, and pyruvate in Pseudomonas citronellolis. J Biol Chem 252, 1257-1263.

Owttrim, G. W. \& Coleman, B. (1986). Purification and characterization of phosphoenolpyruvate carboxylase from a cyanobacterium. J Bacteriol 168, 207-212.

Ozaki, H. \& Shiio, I. (1969). Regulation of the TCA and glyoxylate cycles in Brevibacterium flavum. II. Regulation of phosphoenolpyruvate carboxylase and pyruvate kinase. $J$ Biochem 66, 297-311.

Park, S. M., Shaw-Reid, C., Sinskey, A. J. \& Stephanopoulos, G. 
(1997). Elucidation of anaplerotic pathways in Corynebacterium glutamicum via ${ }^{13} \mathrm{C}-\mathrm{NMR}$ spectroscopy and GC-MS. Appl Microbiol Biotechnol 47, 430-440.

Pátek, M., Eikmanns, B. J., Pátek, J. \& Sahm, H. (1996). Promoters from Corynebacterium glutamicum: cloning, molecular analysis and search for a consensus motif. Microbiology 142, 1297-1309.

Peters-Wendisch, P. G., Eikmanns, B. J., Thierbach, G., Bachmann, B. \& Sahm, H. (1993). Phosphoenolpyruvate carboxylase in Corynebacterium glutamicum is dispensable for growth and lysine production. FEMS Microbiol Lett 112, 269-274.

Peters-Wendisch, P. G., Wendisch, V. F., deGraaf, A. A., Eikmanns, B. J. \& Sahm, H. (1996). $C_{3}$-carboxylation as anaplerotic reaction in phosphoenolpyruvate carboxylase-deficient Corynebacterium glutamicum. Arch Microbiol 165, 387-396.

Peters-Wendisch, P. G., Wendisch, V. F., Paul, S., Eikmanns, B. J. \& Sahm, H. (1997). Pyruvate carboxylase as an anaplerotic enzyme in Corynebacterium glutamicum. Microbiology 143, 1095-1103.

Ruiz-Amil, M., deTorrontegui, G., Palacián, E., Catalina, L. \& Losada, M. (1965). Properties and functions of yeast pyruvate carboxylase. J Biol Chem 240, 3485-3492.

Rylatt, D. B., Keech, D. B. \& Wallace, J. C. (1977). Pyruvate carboxylase: isolation of the biotin-containing tryptic peptide and the determination of its primary sequence. Arch Biochem Biophys 183, 113-122.

Sambrook, J., Fritsch, E. F. \& Maniatis, T. (1989). Molecular Cloning: a Laboratory Manual, 2nd edn. Cold Spring Harbor, NY: Cold Spring Harbor Laboratory.

Samols, D., Thornton, C. G., Murtif, V. L., Kumar, G. K., Haase, C. \& Wood, H. G. (1988). Evolutionary conservation among biotin enzymes. J Biol Chem 263, 6461-6464.

Sanger, F., Nicklen, S. \& Coulson, A. R. (1977). DNA sequencing with chain-terminating inhibitors. Proc Natl Acad Sci USA 74, 5463-5467.

Schäfer, A., Kalinowski, J., Simon, R., Seep-Feldhaus, A. H. \& Puhler, A. (1990). High frequency conjugal plasmid transfer from gram-negative Escherichia coli to various gram-positive coryneform bacteria. J Bacteriol 172, 1663-1666.

Schäfer, A., Tauch, A., Jäger, W., Kalinowski, J., Thierbach, G. \& Pühler, A. (1994). Small mobilizable multi-purpose cloning vectors derived from the Escherichia coli plasmids pK18 and pK19: selection of defined deletions in the chromosome of Corynebacterium glutamicum. Gene 145, 69-73.

Scrutton, M. C. \& Taylor, B. L. (1974). Isolation and characterisation of pyruvate carboxylase from Azotobacter vinelandii OP. Arch Biochem Biophys 164, 641-654.
Scrutton, M. C. \& Young, M. R. (1972). Pyruvate carboxylase. In The Enzymes, vol. 6, pp. 1-35. Edited by P. D. Boyer. New York: Academic Press.

Simon, R., Priefer, U. \& Puhler, A. (1983). A broad host range mobilization system for in vivo genetic engineering: transposon mutagenesis in gram-negative bacteria. Bio/Technology 1, 784 791.

Stucka, R., Dequin, S., Salmon, J.-M. \& Gancedo, C. (1991). DNA sequences in chromosomes II and VII code for pyruvate carboxylase isoenzymes in Saccharomyces cerevisiae: analysis of pyruvate carboxylase-deficient strains. Mol Gen Genet 229, 307-315.

Sundaram, T. K. (1973). Physiological role of pyruvate carboxylase in a thermophilic bacillus. J Bacteriol 113, 549-557.

Thampy, K. G., Huang, W.-Y. \& Wakil, S. J. (1988). A rapid purification method for rat liver pyruvate carboxylase and amino acid sequence analyses of $\mathrm{NH}_{2}$-terminal and biotin peptides. Arch Biochem Biophys 266, 270-276.

Tinoco, I., Borer, P. N., Dengler, B., Levine, M. D., Uhlenbeck, O. C., Crothers, D. M. \& Gralla, J. (1973). Improved estimation of secondary structure in ribonucleic acid. Nat New Biol 246, 40-41. Toh, H., Kondo, H. \& Tanabe, T. (1993). Molecular evolution of biotin-dependent carboxylases. Eur J Biochem 215, 687-696.

Vallino, J. J. \& Stephanopoulos, G. (1993). Metabolic flux distributions in Corynebacterium glutamicum during growth and lysine overproduction. Biotechnol Bioeng 41, 633-646.

Vellanoweth, R. L. \& Rabinowitz, J. C. (1992). The influence of ribosome-binding-site elements on translational efficiency in Bacillus subtilis and Escherichia coli in vivo. Mol Microbiol 6, 1105-1114.

Vieira, J. \& Messing, J. (1982). The pUC plasmids, an M13mp7derived system for insertion mutagenesis and sequencing with synthetic universal primers. Gene 19, 259-268.

Wexler, I. D., Du, Y., Lisgaris, M. V., Mandal, S. K., Freytag, S. O., Yang, B.-S., Liu, T.-C., Kwon, M., Patel, M. S. \& Kerr, D. S. (1994). Primary amino acid sequence and structure of human pyruvate carboxylase. Biochim Biophys Acta 1227, 46-52.

Zhang, J., Xia, W.-L., Brew, K. \& Ahmad, F. (1993). Adipose pyruvate carboxylase: amino acid sequence deduced from cDNA sequencing. Proc Natl Acad Sci USA 90, 1766-1770.

Received 26 August 1997; revised 16 November 1997; accepted 27 November 1997 